\title{
SORPTION PROPERTIES OF POLYMERIC BEADS AND FILMS CONTAINING TETRAOCTYL DIGLYCOLAMIDE TOWARDS EUROPIUM (III) IONS
}

\author{
V. Varchenko*,a, Z. Bunina*,b, K. Bryleva ${ }^{*, c}$, K. Belikov ${ }^{*+, d}$, \\ I. Shcherbakov ${ }^{*, e}$, A. Drapailo ${ }^{\ddagger, f}$, V. Kalchenko ${ }^{\ddagger, g}$
}

\begin{abstract}
* SSI "Institute for Single Crystals" of NAS of Ukraine, 60, Nauky ave., Kharkiv, 61070, Ukraine
† V.N. Karazin Kharkiv National University, School of Chemistry, 4 Svobody sqr.,61022 Kharkiv, Ukraine

$\ddagger$ Institute of Organic Chemistry of NAS of Ukraine, 5, Murmanska Str., Kyiv, 02000, Ukraine
\end{abstract}

a) $\square \underline{\text { varchenko@isc.kh.ua }}$
b) $\square \underline{\text { bunina@isc.kh.ua }}$
c) $\square \underline{\text { bryleva@isc.kh.ua }}$
d) $\square \underline{\text { belikov@karazin.ua }}$
e) $\square \underline{\text { ilias.shcherbakov@isc.kh.ua }}$
f) $\square \underline{\text { a.drapailo@gmail.com }}$
g) $\square$ vik@ioch.kiev.ua

(D) $\begin{aligned} & \text { (Dttps://orcid.org/0000-0002-7369-1637 } \\ & \text { (D) } \frac{\text { https://orcid.org/0000-0002-8639-958X }}{\text { (Dttps://orcid.org/0000-0002-8903-4922 }} \\ & \text { (D) } \frac{\text { https://orcid.org/0000-0002-1682-6064 }}{\text { (Dtps://orcid.org/0000-0002-9450-2153 }} \\ & \text { (Dttps://orcid.org/0000-0002-8701-1380 } \\ & \text { https://orcid.org/0000-0002-0325-7544 }\end{aligned}$

The article presents results obtained during investigation of $\mathrm{Eu}(\mathrm{III})$ ion removal from aqueous solutions using triacetate cellulose films and styrene-divinylbenzene copolymer beads containing tetraoctyl diglycolamide (TODGA). A simple method for manufacturing films containing up to $50 \% \mathrm{w} / \mathrm{w}$ TODGA is provided. Solution acidity effect on the removal rate of Eu(III) ions was studied. Maximum removal of Eu(III) ions was obtained in nitric acid solutions with concentrations of 1-6 mol/l. Additionally, increase in the europium removal rate is also observed at $\mathrm{pH}>2$ for beads and in the $\mathrm{pH}$ range of 2 to 4 for films. In the former case increase in the removal rate is explained by increase in the nitrate ion concentration in the solution and $\mathrm{Eu}\left(\mathrm{NO}_{3}\right)_{3}(\mathrm{TODGA})_{3}$ complex formation, and in the latter case - by decrease in TODGA protonation rate with $\mathrm{pH}$ growth. Observed trends indicate a high similarity in surface sorption mechanisms between the materials studied. Sorption equilibrium of Eu(III) ions onto the styrene-divinylbenzene copolymer beads impregnated with TODGA is adequately fitted to Langmuir sorption isotherm. The maximum sorption capacity of this material for Eu(III) removal from solutions with nitric acid concentration of $1 \mathrm{~mol} / \mathrm{l}$ is $7.4 \mathrm{mg} / \mathrm{g}$. It has been found that the maximum removal rate of Eu(III) ions by the triacetate cellulose films is achieved for TODGA content in the films $\geq 40 \% \mathrm{w} / \mathrm{w}$. The possibility of selective europium sorption from natural water using both beads and films is shown. Although cations present in natural water do not bind to sorbents studied, there is still slight deterioration in sorption properties when moving from model solutions to natural water. Complete desorption of $\mathrm{Eu}(\mathrm{III})$ ions from the film surface is achieved by washing three times with an EDTA solution, $\mathrm{pH}=6.8$. Prepared films can be reused for $\mathrm{Eu}(\mathrm{III})$ ion removal.

Keywords: europium, sorption, TODGA, triacetate cellulose, styrene-divinylbenzene copolymer, removal rate.

\section{Introduction}

Processing and disposal of nuclear wastes as well as determination of trace amounts of radionuclides in the environment objects have become increasingly relevant due to nuclear industry development. A number of ligands was engineered for this purpose such as di(2-ethylhexyl) methane diphosphonic acid [1], quaternary ammonium salts (Aliquat ${ }^{\mathbb{B}}$ ) [2-4], trioctyl phosphine oxide [5,6], octyl phenyl-N,N-diisobutyl carbamoyl phosphine oxide [7-10], dipentyl pentyl phosphonate [11,12]. Up to date, one of the most promising extractants for actinides removal is tetraoctyl diglycolamide (TODGA) (Fig. 1) [13-20]. This ligand has an especially great affinity for americium.

A number of extractive systems based on TODGA [21-23] are known at the moment. They contemplate using toxic and flammable solvents. Solid sorption materials, i.e. a carrier bearing an immobilized ligand on its surface, are more "ecological". The carrier should be inert, resistant to acidic media and radiation. Good examples of such materials are different polymers in the powder, bead, and film forms.

In order to determine ultratrace concentrations of $\alpha$-emitters in natural waters and other environmental objects, preconcentration of the emitter is usually needed. Coprecipitation, extraction, ionic 
exchange, sorption etc. $[24,25]$ are generally used for this purpose. One of the approaches is to use polymeric thin films for radionuclide removal $[26,27]$. In addition to an analyte preconcentration, this method allows significantly decreasing matrix interferences. A great advantage of such films is the possibility of direct measurements using alpha spectrometry. Polymeric films suitable for these purposes usually consist of three main components: a carrier polymer, a ligand, and a plasticizer improving mechanical properties of the films [28]. Film composition is typically adjusted individually in each separate case.<smiles>CCCCCN(CC)C(=O)COCC(=O)N(C)CC</smiles>

Figure 1. Structure of TODGA

It should be noted that film application is not appropriate to remove radionuclides for their processing or disposal. In this case, material with high sorption capacity and developed surface such as polymer particles with immobilized ligands is needed.

It is well known that europium properties resemble those of americium, except europium is not radioactive. For these reasons, primary investigations of sorption properties are often conducted using europium as an analogue for americium.

In this study sorption properties of the styrene-divinylbenzene copolymer beads impregnated with TODGA towards europium ions are examined.

Additionally, the study describes manufacturing of the polymeric films containing the same ligand and their sorption properties towards europium (III). Spent photographic film without any additional plasticizer or other components was proposed to use as a carrier material, which makes the method for film preparation cheaper and simpler.

\section{Experimental part}

Reagents. TODGA was provided by the Institute of Organic Chemistry (Kyiv). 5 g/l stock Eu(III) solution was prepared by dissolution of an accurately weighted amount of europium oxide in nitric acid (Merck). The sorbent based on styrene-divinylbenzene copolymer beads (available from SOE "Smoly", Kamianske, Ukraine) was manufactured in the Institute of Organic Chemistry by the impregnation of the beads using TODGA solution in chloroform and subsequent solvent removal. Bead size was in the range of $63 \ldots 100 \mu \mathrm{m}$. The fraction of TODGA in the material was $40 \%$ by weight. For film manufacturing, photographic film from Kodak Color and chloroform were used. $\mathrm{pH}$ of the solutions were adjusted using $\mathrm{HNO}_{3}$ (Merck) or $\mathrm{NaOH}$ (Merck). Sodium ethylenediaminetetraacetate was used for desorption. All solutions were prepared using deionized water.

Manufacturing of TODGA-containing polymeric films. Photographic cellulose triacetate film after mechanical stripping of a photosensitive emulsion was cut into small pieces and dissolved in $10 \mathrm{ml}$ of chloroform with stirring. A certain amount of TODGA was added to the solution obtained. Total mass of the bare photographic film and TODGA was $0.1 \mathrm{~g}$. The solution obtained was poured in Petri dishes with diameter of $7 \mathrm{~cm}$, which were previously treated with ethanol and hot concentrated nitric acid to degrease the surface. The dishes were lidded and maintained at room temperature for $48 \mathrm{~h}$ until complete chloroform evaporation. The dishes with films formed were filled with water and left for several hours. Then the films were carefully detached from surface of the dish and dried at $25^{\circ} \mathrm{C}$ at reduced pressure for $2 \mathrm{~h}$ to remove residual solvent. Dried films were cut into $2 \times 3 \mathrm{~cm}$ square pieces. In order to obtain optimal film composition, ratio of the photographic film amount to the TODGA amount was varied while total mass of the mixture being kept constant. The inclusion of TODGA in the polymeric matrix was monitored by IR spectroscopy. IR spectra of the films were obtained using a FTIR-8400S spectrometer (Shimadzu, Japan).

Study of sorption properties. Sorption was investigated in a batch mode. $20 \mathrm{ml}$ of the test solution with a certain $\mathrm{Eu}(\mathrm{III})$ concentration was added to $0.05 \mathrm{~g}$ of sorbent or $2 \times 3 \mathrm{~cm}$ film sample in a conical flask. pH was adjusted with $\mathrm{NaOH}$ and $\mathrm{HNO}_{3}$ solutions using a STARTER $3100 \mathrm{pH}$-meter (OHAUS, USA). Solutions with nitric acid concentrations in the range of 0.5 to $6 \mathrm{~mol} / 1$ were prepared by dilution of the corresponding amount of the concentrated nitric acid. Flasks were shaken at $300 \mathrm{rpm}$ for $3 \mathrm{~h}$. Then the film was removed or the sorbent was filtered out. Eu(III) concentration in the solu- 
tion before and after sorption was measured by inductively coupled plasma atomic emission spectrometry using an iCAP 6300 Duo spectrometer (Thermo Scientific, USA).

Removal rate was calculated according to the formula:

$$
R, \%=\frac{c_{0}-c_{e}}{c_{0}} \cdot 100,
$$

where $c_{0}$ is an initial concentration of $\mathrm{Eu}(\mathrm{III})$ ions in the solution; $c_{e}$ is a concentration of $\mathrm{Eu}(\mathrm{III})$ ions after sorption.

In order to obtain sorption isotherms, $20 \mathrm{ml}$ of $\mathrm{Eu}(\mathrm{III})$ solution with concentrations in the range of 2 to $140 \mathrm{mg} / \mathrm{l}$ was added to $0.05 \mathrm{~g}$ of the sorbent. Nitric acid concentration in all solutions was $1 \mathrm{~mol} / \mathrm{l}$.

When studying removal from natural waters, tap water spiked with an aliquot of europium stock solution was used. Concentrated nitric acid was added to the tap water before sorption to obtain concentration of $1 \mathrm{~mol} / \mathrm{l}$.

For desorption and film reuse studies, films were washed with ultrapure water and placed in $20 \mathrm{ml}$ of sodium ethylenediaminetetraacetate (EDTA) solution with concentration of $0.3 \mathrm{~g} / \mathrm{l}$ and $\mathrm{pH}$ 6.8. Desorption was carried out in conditions analogous to those in sorption studies except that the time was $1.5 \mathrm{~h}$. Procedure was performed several times, each time a new portion of the EDTA solution being used. When $\mathrm{Eu}(\mathrm{III})$ was not detected in the solutions after sorption, the films were again washed with ultrapure water, dried and reused for Eu(III) removal as described above.

\section{Results and discussion}

\section{Sorption properties of polymeric beads based on styrene-divinylbenzene impregnated with TODGA}

Acidity effect on the removal rate of $\mathbf{E u ( I I I ) . ~ L a n t h a n i d e s ~ a n d ~ a c t i n i d e s ~ a r e ~ u s u a l l y ~ e x t r a c t e d ~ b y ~}$ TODGA or related ligands from concentrated solutions of nitric acid. It has been concluded that when extracted from nitric acid solutions, nitric acid forms complexes of different composition with TODGA [29], which in turn readily react with europium cations. However, in this work Eu(III) sorption was studied in a wider acidity range to choose the most optimal conditions for removal: in nitric acid solutions with concentrations of $6 \mathrm{~mol} / 1$ to $0.5 \mathrm{~mol} / 1$ and in solutions with $\mathrm{pH}$ of 1 to $7 . \mathrm{pH}>7$ was not studied because hydrolysis of europium may occur in this conditions. Sorption was carried out at an initial $\mathrm{Eu}$ (III) concentration of $20 \mathrm{mg} / \mathrm{l}$. Obtained results are shown in Fig. 2.

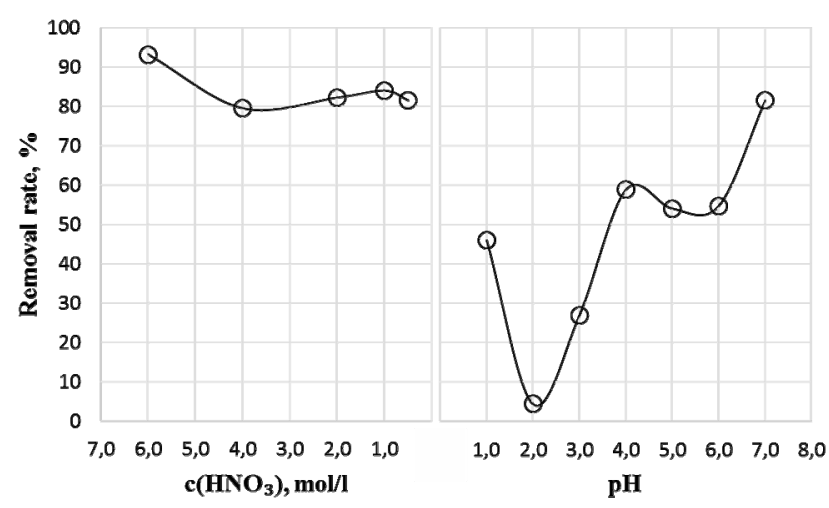

Figure 2. Acidity effect on removal rate of $\mathrm{Eu}(\mathrm{III})$

Fig. 2 illustrates that the maximal removal of Eu(III) was observed in the solutions with high nitric acid content. Authors of the publication [30] demonstrate decrease in the removal rate with increase in $\mathrm{HNO}_{3}$ concentration and relate this phenomenon to competition between $\mathrm{Eu}(\mathrm{III})$ and $\mathrm{H}^{+}$ions. In our work such effect was not observed. Oppositely, the removal rate began to increase again with further decrease in solution acidity $(\mathrm{pH}>2)$. Previously, complex formation between Eu(III) and TODGA was studied. It has been concluded that it most probably occurs according to the following scheme [30]:

$$
\mathrm{Eu}^{3+}+3 \mathrm{NO}_{3}^{-}+3 \mathrm{TODGA} \rightarrow \mathrm{Eu}\left(\mathrm{NO}_{3}\right)_{3} \mathrm{TODGA}_{3}
$$


Therefore, formation of a different-ligand complex occurs, with nitrate anions directly participating in the complex formation. That explains increase in the europium removal rate from solutions containing nitric acid. It is also confirmed by the fact that changing of nitrate ions for sulphate ions dramatically decreases the europium removal rate (about $6 \%$ at the initial Eu(III) concentration of $20 \mathrm{mg} / \mathrm{l}$ ). Subsequent increase in the europium removal rate with increase in $\mathrm{pH}$ of solution $>2$ can be explained as following. Though basic properties of TODGA are rather weak, as far as it is amide with tertiary nitrogen atoms and long alkyl substituents, it still may bind to nitric acid. Amides are protonated by strong acids at an oxygen atom because the cation formed in such way is stabilized due to mesomeric effect. So the amide oxygen participating in the complex formation with europium is involved in this process. Therefore, in addition to europium binding, competitive protonation of TODGA should be taking into account. Consequently, increase in the removal rate after $\mathrm{pH}$ of 2 relates to decrease in the protonation rate of the TODGA amide moiety.

Sorption isotherm of $\mathbf{E u}(\mathbf{I I I})$. Sorption isotherms were obtained by varying concentration of $\mathrm{Eu}(\mathrm{III})$ ions in the solutions for sorption.

Sorption capacity was calculated according to the equation:

$$
q=\frac{\left(c_{0}-c_{e}\right) V}{m}
$$

where $c_{0}$ is an initial concentration of $\mathrm{Eu}^{3+}, \mathrm{mg} / \mathrm{l} ; c_{e}$ is a concentration of $\mathrm{Eu}^{3+}$ in the solution after sorption; $V$ is a volume of the solution, $1 ; m$ is a mass of the sorbent, $\mathrm{g}$.

The isotherm obtained is shown in Fig. 3.

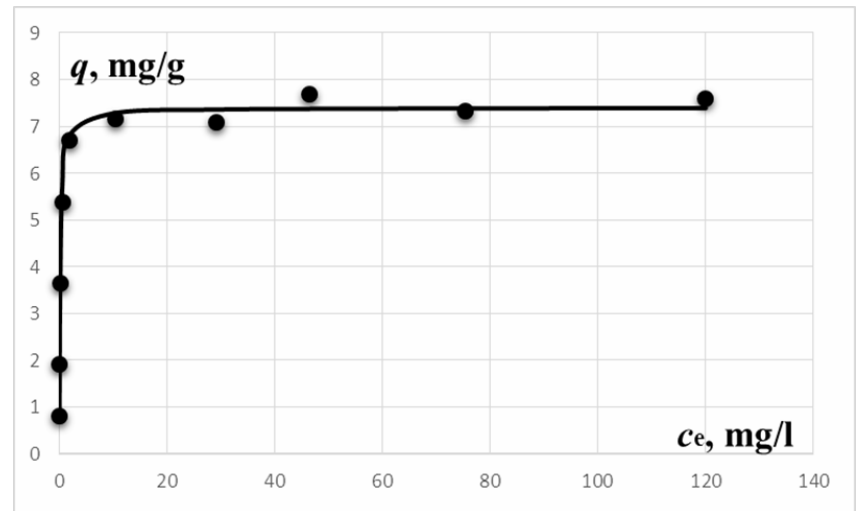

Figure 3. Sorption isotherm of Eu(III) ions

This isotherm is an isotherm of H-type according to the classification in [31]. According to calculations, data obtained is well fitted to Langmuir sorption isotherm:

$$
q=q_{\infty} \frac{K_{L} c_{e}}{1+K_{L} c_{e}},
$$

where $q$ is a sorption capacity; $q_{\infty}$ is a maximal sorption capacity; $K_{L}$ is a Langmuir adsorption constant; $c_{e}$ is an equilibrium concentration of $\mathrm{Eu}(\mathrm{III})$ ions.

Coefficients $q_{\infty}$ and $K_{L}$ in the equation (3) were determined by a nonlinear method of least squares. Values obtained as well as values of squared correlation coefficient are provided in Table 1. The obedience of the sorption process to Langmuir model suggests an equivalence of all centers on the sorbent surface without any interaction between particles as well as formation of a monolayer of adsorbed particles [32].

Table 1. Parameters of Langmuir sorption isotherm equation

\begin{tabular}{c|c|c}
\hline$K_{L},(1 / \mathrm{mg})$ & $q_{\infty}, \mathrm{mg} / \mathrm{g}$ & $R^{2}$ \\
\hline 6.2 & 7.4 & 0.988 \\
\hline
\end{tabular}

Removal of $\mathbf{E u ( I I I )}$ from natural waters. It is well known that natural water contains cations that can interfere target ion sorption. Table 2 provides content of $\mathrm{Eu}(\mathrm{III})$ ions and ions usually present in natural water before and after sorption. 
Table 2. Cationic composition of water spiked with Eu(III) before and after sorption

\begin{tabular}{c|c|c}
\hline Ion & Before sorption, $\mathrm{mg} / \mathrm{l}$ & After sorption, $\mathrm{mg} / \mathrm{l}$ \\
\hline $\mathrm{Ca}^{2+}$ & 90 & 90 \\
$\mathrm{Mg}^{2+}$ & 49 & 49 \\
$\mathrm{Sr}^{2+}$ & 0.91 & 0.90 \\
$\mathrm{Al}^{3+}$ & 0.12 & 0.12 \\
$\mathrm{Fe}^{3+}$ & 0.50 & 0.48 \\
$\mathrm{~K}^{+}$ & 9.9 & 10.0 \\
$\mathrm{Na}^{+}$ & 107 & 111 \\
$\mathbf{E u}(\mathbf{I I I})$ & $\mathbf{1 9}$ & $\mathbf{5 . 3}$ \\
\hline
\end{tabular}

As can be concluded from Table 2, ions present in the natural water do not bind to the investigated material; however, decrease in the removal rate compared to model solutions is observed: $70 \%$ for natural water and $90 \%$ for model solutions (at the initial Eu(III) concentration of $19 \mathrm{mg} / \mathrm{l}$ ). Such deterioration can be explained considering blocking of the sorbent active centers by other components from water, e.g. organic compounds contained therein. However, this issue needs further study.

\section{Sorption properties of polymeric films containing TODGA}

Optimal film composition determination. Fig. 4 provides an exemplary IR-spectrum of triacetyl cellulose film with incorporated TODGA molecules. The spectrum includes the absorption band of stretch vibrations of the TODGA amide group as a nonassociated form $v(\mathrm{C}=\mathrm{O})$ at $1650 \mathrm{~cm}^{-1}$ and the absorption band of stretch vibrations of the C-O-C bond at $1120 \mathrm{~cm}^{-1}$, two bands at 2860 and $2920 \mathrm{~cm}^{-1}$, which correspond to symmetric and asymmetric stretch vibrations of the alkyl groups in the hydrocarbon substituents of TODGA, and the band of the deformation vibrations of $\mathrm{C}-\mathrm{H}$ from $-\mathrm{CH}_{2}-$ and $\mathrm{CH}_{3}$ groups at 1460 and $1370 \mathrm{~cm}^{-1}$. Bands at 1740 and $1230 \mathrm{~cm}^{-1}$ or $1040 \mathrm{~cm}^{-1}$ correspond to the vibrations of $\mathrm{C}-\mathrm{O}-\mathrm{C}$ in ester or ether groups, respectively, which pertain to the matrix material.

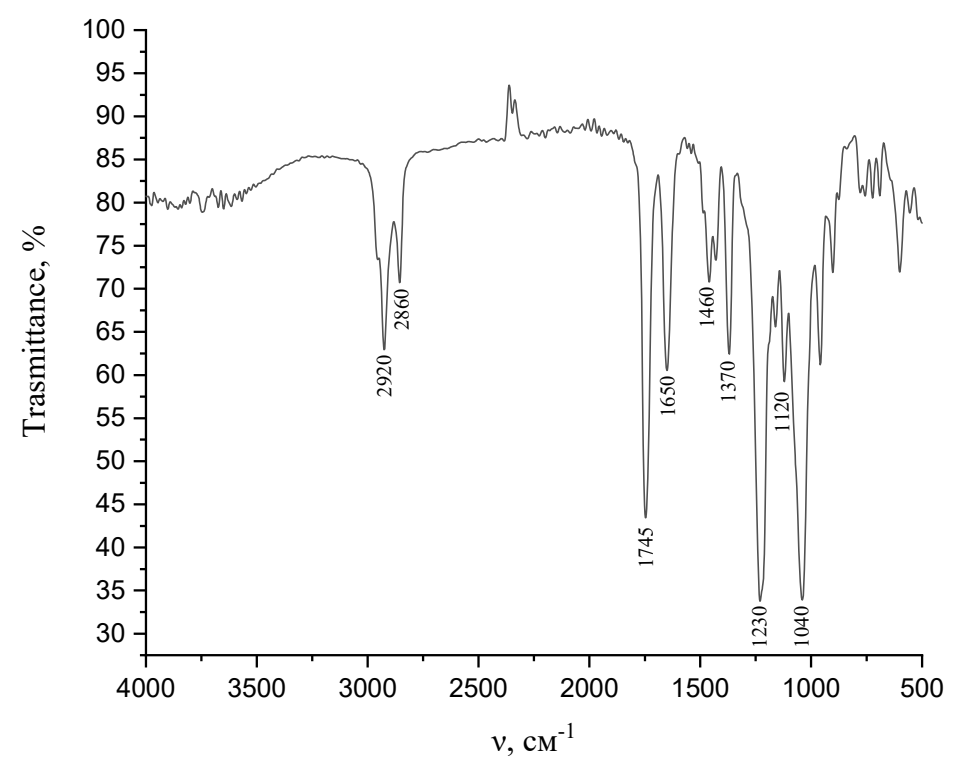

Figure 4. IR-spectrum of triacetyl cellulose film modified with TODGA.

Sorption of $\mathrm{Eu}(\mathrm{III})$ ions on the films obtained was carried out in $1 \mathrm{M} \mathrm{HNO}_{3}$. Removal rate of europium $v s$. weight fraction of TODGA in polymeric film is shown in Fig. 5.

Increase in the removal rate with increase in TODGA content in the film is observed up to $40 \%$ by weight and then the removal rate becomes essentially constant. Accordingly, optimal film composition was chosen to be $40 \%$ by weight of TODGA and $60 \%$ by weight of the photographic film.

Acidity effect on the removal rate of Eu(III). Removal of $\mathrm{Eu}(\mathrm{III})$ by the films was investigated in the wide $\mathrm{pH}$ range: in nitric acid solutions with concentrations of $6 \mathrm{~mol} / \mathrm{l}$ to $1 \mathrm{~mol} / \mathrm{l}$ and in the solu- 
tions with $\mathrm{pH}$ of 1 to 7 (the initial $\mathrm{Eu}(\mathrm{III})$ concentration was $0.3 \mathrm{mg} / \mathrm{l}$ ). The relationship obtained is shown in Fig. 6.

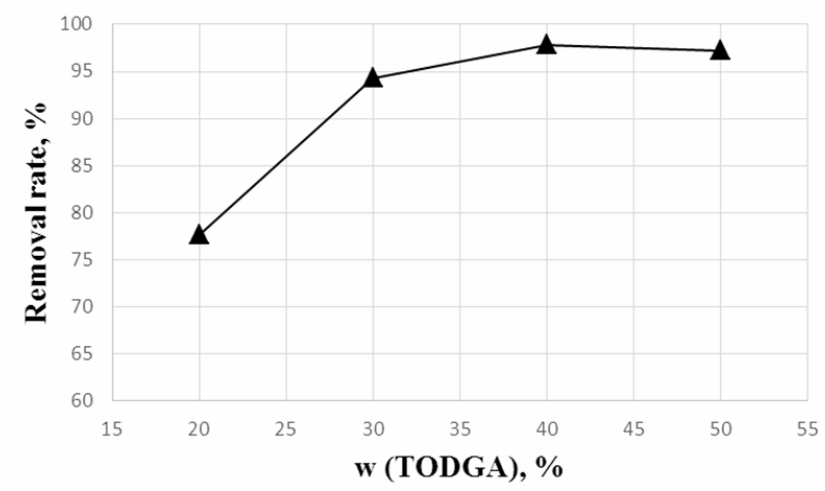

Figure 5. Eu(III) removal rate $v s$. weight fraction of TODGA in the film

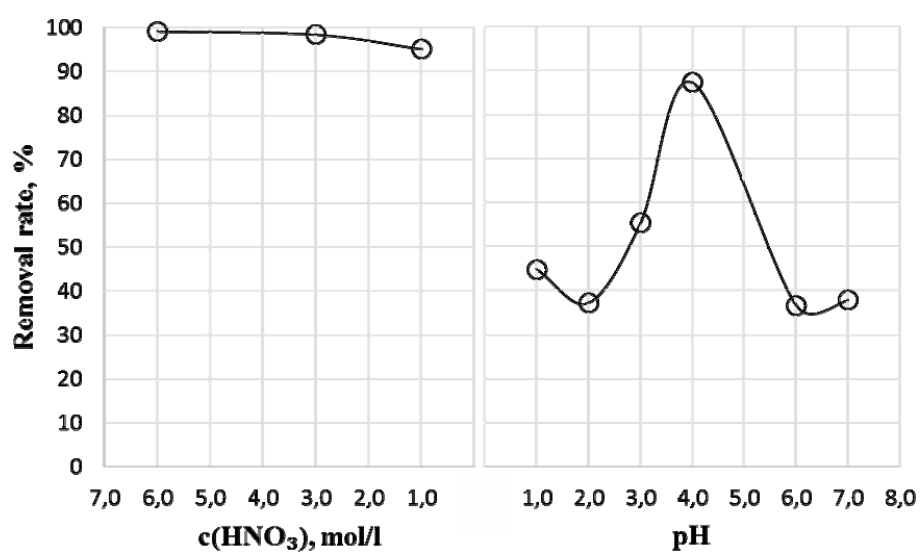

Figure 6. Eu(III) removal rate $v s$. acidity of the solution

In general, the relationship is even more complicated than that observed for styrene-divinylbenzene copolymer beads impregnated by TODGA. As for polymeric beads investigated, the maximal removal rate was observed in solutions with high nitric acid concentrations. Notably, europium removal rate increases in the $\mathrm{pH}$ range of 2 to 4 in both systems studied. Further increase in $\mathrm{pH}$ leads to the growth of the europium removal efficiency in the case of the beads and on the contrary to the decrease in the efficiency in the case of the films, which can be associated with changes in sorption mechanism.

Removal of Eu(III) from natural waters. The removal of Eu(III) from natural water spiked with europium was studied using the polymeric films. As for polymeric beads, slight deterioration of sorption properties was observed: about $80 \%$ of europium ions was removed from the natural water, while $>95 \%$ was removed from model solutions at the initial concentration of the analyte of $0.3 \mathrm{mg} / \mathrm{l}$.

Regeneration and reuse of the films. The aim of the following experiment was to elucidate the possibility of the film reuse. Eu(III) removal occurred the most efficiently in a highly acidic medium, so an EDTA solution with $\mathrm{pH}$ of 6.8 was decided to be used for desorption. Table 3 illustrates results obtained during desorption process investigation.

Table 3. Desorption of Eu(III) from the films

\begin{tabular}{c|c}
\hline No. of cycle & Eu(III) content in the solution, $\mathrm{mg} / 1$ \\
\hline 1 & 0.13 \\
2 & 0.12 \\
3 & $<0.005$ \\
\hline
\end{tabular}

It has been found that complete desorption (>99\%) of Eu (III) from the film was achieved after three cycles of washing with the EDTA solution, while integrity and mechanical properties of the films were remained intact. Repeated sorption of $\mathrm{Eu}(\mathrm{III})$ was performed on the films regenerated. Such 
regeneration was found to not influence on the sorption properties of the films: Eu(III) removal rate was $95 \%$ and $96 \%$ for new and regenerated films, respectively. Accordingly, the films can be used twice. However, subsequent purification cycles led to an abrupt deterioration of physical properties: the film lost her elasticity and became soft and sticky. This is likely to be explained by gradual saponification of cellulose triacetate with the nitric acid solution.

\section{Conclusions}

Sorption properties of the styrene-divinylbenzene copolymer beads impregnated with TODGA and of the polymeric films based on cellulose triacetate containing TODGA towards Eu(III) were studied. It is found that the maximal removal of $\mathrm{Eu}(\mathrm{III})$ ions is observed both in the concentrated nitric acid solutions (1-6 mol/l) and in the solutions with higher $\mathrm{pH}$ values: in the range of 4-7 for the beads and 3-4 for the films, with the minimal removal being observed at $\mathrm{pH}=1-2$ for both materials. Sorption equilibrium of $\mathrm{Eu}(\mathrm{III})$ ions on the styrene-divinylbenzene copolymer beads is adequately $\left(\mathrm{R}^{2}=0.988\right)$ fitted by Langmuir adsorption isotherm. According to calculations, the maximal sorption capacity is $7.4 \mathrm{mg} / \mathrm{g}$ in the nitric acid solutions with concentration of $1 \mathrm{~mol} / \mathrm{l}$. Removal of Eu(III) ions from natural water is slightly less effective than that from model solutions for both films and beads. However, it is found that metal cations present in natural water do to not sorb in such systems. The possibility to use the polymeric films twice without any deterioration of their sorption properties was shown.

The study is financially supported by the National Academy of Sciences of Ukraine within the project "Novel polymeric sorption materials for radioecological monitoring", state registration no. $0119 \mathrm{U} 101248$.

\section{References}

1. Chiarizia, R.; McAlister, D. R.; Herlinger, A. W. Trivalent Actinide and Lanthanide Separations by Dialkyl-Substituted Diphosphonic Acids. Sep. Sci. Technol. 2005, 40 (1-3), 69-90. https://doi.org/10.1081/SS-200041762.

2. Chiarizia, R.; Gatrone, R. C.; Horwitz, E. P. Am(III) and Eu(III) Extraction by Aliquat-336 and Benzyl Substituted Quaternary Ammonium Salts from Nitrate and Thiocyanate Solutions. Solvent Extr. Ion Exch. 1995, 13 (4), 615-645. https://doi.org/10.1080/07366299508918295.

3. Landgren, A.; Liljenzin, J.-O. Extraction Behaviour of Technetium and Actinides in the Aliquat336/Nitric acid system. Solvent Extr. Ion Exch. 1999, 17 (6), 1387-1401. https://doi.org/10.1080/07366299908934654.

4. Khopkar, P. K.; Mathur, J. N. Synergistic Extraction of Some Trivalent Actinides and Lanthanides by Thenoyltrifluoroacetone and Aliquat Chloride. J. Inorg. Nucl. Chem. 1977, 39 (11), 2063-2067. https://doi.org/10.1016/0022-1902(77)80548-4.

5. Yuan, L.; Sun, M.; Liao, X.; Zhao, Y.; Chai, Z.; Shi, W. Solvent Extraction of U(VI) by Trioctylphosphine Oxide Using a Room-Temperature Ionic Liquid. Sci. China Chem. 2014, 57 (11), 1432-1438. https://doi.org/10.1007/s11426-014-5194-8.

6. Kosyakov, V. N.; Yerin, E. A.; Vitutnev, V. M. The Use of Trioctylphosphine Oxide for Solvent Extraction Recovery and Purification of Transplutonium Elements. J. Radioanal. Chem. 1980, 56 (1-2), 83-92. https://doi.org/10.1007/BF02516940.

7. Antony, M. P.; Kumaresan, R.; Suneesh, A. S.; Rajeswari, S.; Robertselvan, B.; Sukumaran, V.; Manivannan, R.; Syamala, K. V.; Venkatesan, K. A.; Srinivasan, T. G.; Vasudeva Rao, P. R. Development of a CMPO Based Extraction Process for Partitioning of Minor Actinides and Demonstration with Geneuine Fast Reactor Fuel Solution (155 GWd/Te). Radiochim. Acta 2011, 99 (4), 207-215. https://doi.org/10.1524/ract.2011.1815.

8. Mathur, J. N.; Murali, M. S.; Iyer, R. H.; Ramanujam, A.; Dhami, P. S.; Gopalakrishnan, V.; Rao, M. K.; Badheka, L. P.; Banerji, A. Extraction Chromatographic Separation of Minor Actinides from PUREX High-Level Wastes Using CMPO. Nucl. Technol. 1995, 109 (2), 216-225. https://doi.org/10.13182/NT95-A35054.

9. Mathur, J. N.; Murali, M. S.; Natarajan, P. R.; Badheka, L. P.; Banerji, A.; Ramanujam, A.; Dhami, P. S.; Gopalakrishnan, V.; Dhumwad, R. K.; Rao, M. K. Partitioning of Actinides from High-Level Waste Streams of Purex Process Using Mixtures of CMPO and TBP in Dodecane. Waste Manag. 1993, 13 (4), 317-325. https://doi.org/10.1016/0956-053X(93)90060-A. 
10. Dhami, P. S.; Chitnis, R. R.; Gopalakrishnan, V.; Wattal, P. K.; Ramanujam, A.; Bauri, A. K. Studies on the Partitioning of Actinides from High Level Waste Using a Mixture of HDEHP and CMPO as Extractant. Sep. Sci. Technol. 2001, 36 (2), 325-335. https://doi.org/10.1081/SS100001082.

11. Prabhu, S. P.; Prasad, T. L.; Rao, D. D. Use of Solid Extraction Chromatography for Determination of Uranium in Sea Water and Brine. Desalination Water Treat. 2016, 57 (55), 26845-26849. https://doi.org/10.1080/19443994.2016.1139104.

12. Skinner, M.; Knight, D. The Behaviour of Selected Fission Products and Actinides on UTEVA® Resin. J. Radioanal. Nucl. Chem. 2016, 307 (3), 2549-2555. https://doi.org/10.1007/s10967-0164706-8.

13. Panja, S.; Mohapatra, P. K.; Tripathi, S. C.; Gandhi, P. M.; Janardan, P. A Highly Efficient Solvent System Containing TODGA in Room Temperature Ionic Liquids for Actinide Extraction. Sep. Purif. Technol. 2012, 96, 289-295. https://doi.org/10.1016/j.seppur.2012.06.015.

14. Gujar, R. B.; Ansari, S. A.; Prabhu, D. R.; Pathak, P. N.; Sengupta, A.; Thulasidas, S. K.; Mohapatra, P. K.; Manchanda, V. K. Actinide Partitioning with a Modified TODGA Solvent: CounterCurrent Extraction Studies with Simulated High Level Waste. Solvent Extr. Ion Exch. 2012, 30 (2), 156-170. https://doi.org/10.1080/07366299.2011.609392.

15. Modolo, G.; Asp, H.; Schreinemachers, C.; Vijgen, H. Development of a TODGA Based Process for Partitioning of Actinides from a PUREX Raffinate Part I: Batch Extraction Optimization Studies and Stability Tests. Solvent Extr. Ion Exch. 2007, 25 (6), 703-721. https://doi.org/10.1080/07366290701634578.

16. Ansari, S. A.; Pathak, P. N.; Husain, M.; Prasad, A. K.; Parmar, V. S.; Manchanda, V. K. Extraction of Actinides Using $\mathrm{N}, \mathrm{N}, \mathrm{N}^{\prime}, \mathrm{N}^{\prime}$-Tetraoctyl Diglycolamide (TODGA): A Thermodynamic Study. Radiochim. Acta. 2006, 94 (6-7). https://doi.org/10.1524/ract.2006.94.6.307.

17. Ansari, S. A.; Pathak, P. N.; Manchanda, V. K.; Husain, M.; Prasad, A. K.; Parmar, V. S. $\mathrm{N}, \mathrm{N}, \mathrm{N}^{\prime}, \mathrm{N}^{\prime}$-Tetraoctyl Diglycolamide (TODGA): A Promising Extractant for Actinide-Partitioning from High-Level Waste (HLW). Solvent Extr. Ion Exch. 2005, 23 (4), 463-479. https://doi.org/10.1081/SEI-200066296.

18. Reilly, S. D.; Gaunt, A. J.; Scott, B. L.; Modolo, G.; Iqbal, M.; Verboom, W.; Sarsfield, M. J. Plutonium(IV) Complexation by Diglycolamide Ligands - coordination Chemistry Insight into TODGA-Based Actinide Separations. Chem. Commun. 2012, 48 (78), 9732. https://doi.org/10.1039/c2cc34967a.

19. Ansari, S. A.; Mohapatra, P. K.; Manchanda, V. K. Recovery of Actinides and Lanthanides from High-Level Waste Using Hollow-Fiber Supported Liquid Membrane with TODGA as the Carrier. Ind. Eng. Chem. Res. 2009, 48 (18), 8605-8612. https://doi.org/10.1021/ie900265y.

20. Iqbal, M.; Huskens, J.; Verboom, W.; Sypula, M.; Modolo, G. Synthesis and Am/Eu Extraction of Novel TODGA Derivatives. Supramol. Chem. 2010, 22 (11-12), 827-837. https://doi.org/10.1080/10610278.2010.506553.

21. Suzuki, H.; Sasaki, Y.; Sugo, Y.; Apichaibukol, A.; Kimura, T. Extraction and Separation of $\mathrm{Am}(\mathrm{III})$ and $\mathrm{Sr}(\mathrm{II})$ by $\mathrm{N}, \mathrm{N}, \mathrm{N}^{\prime}, \mathrm{N}^{\prime}$-Tetraoctyl-3-Oxapentanediamide (TODGA). Radiochim. Acta 2004, 92 (8). https://doi.org/10.1524/ract.92.8.463.39276.

22. Zhang, Y.; Liu, Z.; Fan, F.; Zhu, L.; Shen, Y. Extraction of Uranium and Thorium from Nitric Acid Solution by TODGA in Ionic Liquids. Sep. Sci. Technol. 2014, 49 (12), 1895-1902. https://doi.org/10.1080/01496395.2014.903279.

23. Apichaibukol, A.; Sasaki, Y.; Morita, Y. Effect of DTPA on the Extractions of Actinides(III) and Lanthanides(III) from Nitrate Solution into Todga/n-Dodecane. Solvent Extr. Ion Exch. 2004, 22 (6), 997-1011. https://doi.org/10.1081/SEI-200037727.

24. Goldstein, S. J.; Rodriguez, J. M.; Lujan, N. Measurement and Application of Uranium Isotopes for Human and Environmental Monitoring. Health Phys. 1997, 72 (1), 10-18. https://doi.org/10.1097/00004032-199701000-00002.

25. Popov, L. Method for Determination of Uranium Isotopes in Environmental Samples by Liquidliquid Extraction with Triisooctylamine/xylene in Hydrochloric Media and Alpha Spectrometry. Appl. Radiat. Isot. 2012, 70 (10), 2370-2376. https://doi.org/10.1016/j.apradiso.2012.05.019. 
26. Chavan, V.; Paul, S.; Pandey, A. K.; Kalsi, P. C.; Goswami, A. Thin Extractive Membrane for Monitoring Actinides in Aqueous Streams. J. Hazard. Mater. 2013, 260, 53-60. https://doi.org/10.1016/j.jhazmat.2013.05.007.

27. Gonzáles, E. R.; Peterson, D. S. Rapid Radiochemical Sample Preparation for Alpha Spectrometry Using Polymer Ligand Films. J. Radioanal. Nucl. Chem. 2009, 282 (2), 543-547. https://doi.org/10.1007/s10967-009-0218-0.

28. Almeida, M. I. G. S.; Cattrall, R. W.; Kolev, S. D. Recent Trends in Extraction and Transport of Metal Ions Using Polymer Inclusion Membranes (PIMs). J. Membr. Sci. 2012, 415-416, 9-23. https://doi.org/10.1016/j.memsci.2012.06.006.

29. Bell, K.; Geist, A.; McLachlan, F.; Modolo, G.; Taylor, R.; Wilden, A. Nitric Acid Extraction into TODGA. Procedia Chem. 2012, 7, 152-159. https://doi.org/10.1016/j.proche.2012.10.026.

30. Sengupta, A.; Ali, S. M.; Shenoy, K. T. Understanding the Complexation of the $\mathrm{Eu}^{3+}$ Ion with TODGA, CMPO, TOPO and DMDBTDMA: Extraction, Luminescence and Theoretical Investigation. Polyhedron. 2016, 117, 612-622. https://doi.org/10.1016/j.poly.2016.06.037.

31. Adsorption from Solution at the Solid/liquid Interface; Parfitt, G. D., Rochester, C. H., Eds.; Academic Press: London; New York, 1983.

32. Foo, K. Y.; Hameed, B. H. Insights into the Modeling of Adsorption Isotherm Systems. Chem. Eng. J. 2010, 156 (1), 2-10. https://doi.org/10.1016/j.cej.2009.09.013.

Надіслано до редакиії 17 вересня 2020 р.

В.В. Варченко*, 3.Ю. Буніна*, К.Ю. Брильова*, К.М. Бєліков*, , І.Б.-Х. Щербаков*, А.Б. Драпайло В.І. Кальченко ${ }^{\ddagger}$. Сорбційні властивості полімерних гранул та плівок, що містять тетраоктилдиглікольамід, по відношенню до йонів європію (III).

* НТК «Інститут монокристалів» НАН України, пр. Науки, 60, 61070, Харків, Україна

† Харківський національний університет імені В.Н. Каразіна, пл. Свободи, 4, 61022, Харків, Україна

Ғ Інститут органічної хімії НАН України, вул. Мурманська, 5, 02000, Київ, Україна

У цій статті наведено результати дослідження вилучення йонів Eu(III) з водних розчинів плівками на основі триацетату целюлози і гранулами кополімеру стирену та дивінілбензену, що містять тетраоктилдиглікольамід (TODGA). Запропоновано простий спосіб отримання плівок триацетилцелюлози, що містять до 50 мас. \% TODGA. Для вказаних матеріалів досліджено залежності ступеня вилучення йонів Еu(III) від кислотності розчинів. Максимальне вилучення йонів $\mathrm{Eu}(\mathrm{III})$ спостерігається у розчинах нітратної кислоти 3 концентраціями 1-6 моль/л. Крім того, збільшення ступеня вилучення європію відбувається також при pH > 2 для гранул, і в інтервалі рН від 2 до 4 для плівок. В першому випадку збільшення ступеня вилучення пояснюється збільшенням концентрації нітрат-іонів у розчині та утворенням комплексу Eu(NO $\left.)_{3}\right)_{3}\left(\mathrm{TODGA}_{3}\right.$, а у другому зменшенням ступеня протонування TODGA зі збільшенням $\mathrm{pH}$. Характер залежностей вказує на ідентичність механізмів сорбції на поверхні досліджуваних матеріалів. Сорбційна рівновага йонів Еu(III) на гранулах кополімеру стирену та дивінілбензену, імпрегнованих TODGA, задовільно описується ізотермою адсорбції Ленгмюра. Максимальна сорбційні ємність такого матеріалу при вилученні йонів Eu(III) 3 розчинів з концентрацією нітратної кислоти 1 моль/л становить 7.4 мг/г. Встановлено, що максимальний ступінь вилучення йонів Eu(III) плівками на основі триацетилцелюлози досягається при вмісті в них TODGA $\geq 40$ мас. \%. Показано можливість селективної сорбції європію з природної води як з використанням гранул, так і плівок. Хоча катіони, що містяться у природній воді, не зв'язуються досліджуваними сорбентами, при переході від модельних розчинів до природної води тим не менше спостерігається незначне погіршення сорбційних властивостей. Повна десорбція йонів Еu(III) з поверхні плівок досягається при трикратному промиванні розчином ЕДТА з $\mathrm{pH}=6.8$. Отримані плівки можна удруге використовувати для вилучення йонів $\mathrm{Eu}(\mathrm{III})$.

Ключові слова: європій, сорбція, TODGA, триацетат целюлози, сополімер стирену з дивінілбензеном, ступінь вилучення.

В.В. Варченко*, 3.Ю. Бунина*, Е.Ю. Брылева*, К.Н. Беликов*, , І.Б.-Х. Щербаков*, А.Б. Драпайло В.И. Кальченко ${ }^{\ddagger}$. Сорбционные свойства полимерных гранул и пленок, содержащих тетраоктилдигликольамид, по отношению к ионам европия (III).

* НТК «Институт монокристаллов» НАН Украины, пр. Науки, 60, 61070, Харьков, Украина

† Харьковский национальный университет имени В.Н. Каразина, пл. Свободы, 4, 61022, Харьков, Украина

‡ Институт органической химии НАН Украины, ул. Мурманская, 5, 02000, Киев, Украина 
Sorption properties of polymeric beads and films containing tetraoctyl diglycolamide ...

В настоящей статье приведены результаты исследования извлечения ионов Еu(III) из водных растворов гранулами сополимера стирола и дивинилбензола и пленками на основе триацетата целлюлозы, содержащими тетраоктилдигликольамид (TODGA). Предложен простой способ получения пленок триацетилцеллюлозы, содержащих до 50 мас. \% TODGA. Для данных материалов изучены зависимости степени извлечения ионов Еu(III) от кислотности растворов. Максимальное извлечение ионов Еu(III) наблюдается в растворах азотной кислоты с концентрацией 1-6 моль/л. Кроме того, увеличение степени извлечения европия происходит также при $\mathrm{pH}>2$ для гранул, и в интервале $\mathrm{pH}$ от 2 до 4 для пленок. В первом случае увеличение степени извлечения объясняется увеличением концентрации нитрат-ионов в растворе и образованием комплекса $\mathrm{Eu}\left(\mathrm{NO}_{3}\right)_{3}(\mathrm{TODGA})_{3}$, а во втором уменьшением степени протонирования TODGA c увеличением $\mathrm{pH}$. Характер зависимостей указывает на идентичность механизмов сорбции на поверхности исследованных материалов. Сорбционное равновесие ионов Eu(III) на гранулах сополимера стирола и дивинилбензола, импрегнированных TODGA, удовлетворительно описывается изотермой адсорбции Ленгмюра. Максимальная сорбционная емкость такого материала при извлечении ионов Еu(III) из растворов с концентрацией азотной кислоты 1 моль/л составляет 7.4 мг/г. Установлено, что максимальная степень извлечения ионов Еu(III) пленками на основе триацетилцеллюлозы достигается при содержании в них TODGA $\geq 40$ мас. \%. Показана возможность селективной сорбции европия из природной воды как с использованием гранул, так и пленок. Хотя катионы, содержащиеся в природной воде, не связываются изучаемыми сорбентами, при переходе от модельных растворов к природной воде тем не менее наблюдается незначительное ухудшение сорбционных свойств. Полная десорбция ионов Еu(III) с поверхности пленок достигается при трехкратном промывании раствором ЭДТА с $\mathrm{pH}=6.8$. Полученные пленки можно повторно использовать для извлечения ионов $\mathrm{Eu}(\mathrm{III})$.

Ключевые слова: европий, сорбция, TODGA, триацетат целлюлозы, сополимер стирола с дивинилбензолом, степень извлечения.

Kharkiv University Bulletin. Chemical Series. Issue 35 (58), 2020 